first three Indian missions or doctrinas, and a polemic report on the opposition to the Franciscan missions mounted by the firmly entrenched Jesuits who wanted a monopoly in the care of the Indians.

The importance of this document lies in the fact of its uniqueness: there is no other earlier Franciscan document covering these first years. The manuscript was discovered in the Franciscan archive in Pastrana, Spain early in this century. It was published in short summary in the Archivo lbero Americano, I (1914), and has been used since then by Brazilian Franciscan historians, although not published in full until now, to commemorate the 300th anniversary of the Franciscan Province of the Immaculate Conception (1675-1975).

M.C.K.

\title{
Jose Maria Ots Capdequi (1893-1975)
}

José María Ots Capdequí died on September 25, 1975 at Benimodo, Valencia, Spain. He was the historian of Derecho Indiano who accomplished most for the study and systematization of Spanish institutions in the Americas. Despite this distinction, Ots Capdequí did not have any major student in his specialty, although his writings have trained almost a generation of them.

Ots Capdequí was born in Valencia on December 5, 1893 of an affluent landowning family. He studied in his native city in the Instituto Nacional de Segunda Enseñanza, a department of the University of Valencia. He obtained his licentiate in Law from the same institution. Thereupon, he began his doctoral studies at the Universidad Central de Madrid (1914-1915). The only academic center at that time in Spain which could grant the doctor's degree in Law. A student of Eduardo de Hinojosa and of Rafael Altamira, the two outstanding Spanish historians of Law of that time, the young Ots was a fellow of the Centro de Estudios Históricos (Madrid 1916-1920). Later, he continued his studies on a scholarship in Paris (1922) and Berlin (1923). In competition he won the chair of History of Spanish Law in the University of Oviedo (1921) and later the same chair in that of Seville (1924) and then of Valencia (1931). In the latter school, he also was elected Dean of the Faculty of Law (1936). A short time later he was appointed General Director of Universities by the Ministerio de Instrucción Pública. Shortly after his transfer to Valencia in 1931, Ots assumed charge of the administration of the "Centro de Estudios de Historia de América," attached to the University of Seville (today the Escuela de Estudios Hispano-Americanos).

In the years 1934-1938, Ots Capdequí frequently visited the Americas where he gave lectures or conducted seminars in the universities of La Plata, Buenos Aires, Córdoba, Rosario, Bahía Blanca, Montevideo, Bogotá, Medellín, Guadalajara, Morelia, México and Havana.

He chose voluntary exile, as did so many university professors, at the end of the Spanish Civil War and established his residence in Bogotá. A special chair was created for him of History of Spanish Law in America. It was stipulated that Ots would teach not only at the Universidad Nacional. Consequently, he conducted classes at the Colegio Mayor de Nuestra Señora del Rosario, 
the Universidad Javeriana, the Universidad Libre and the Externado de Derecho, all in Bogotá.

Upon invitation, Ots also offered courses in the universities of Santo Domingo (1945), Puerto Rico (1946), San Marcos in Lima, and Quito (1952).

In March 1953, for family reasons, he returned to Spain, and established his residence in the town of Benimodo where he owned the family residence and some landed properties. However, he still maintained his contact with America. Thus, he was a member of the Mesa Redonda of Americanists (Caracas, 1960) and gave lectures in Bogotá under the sponsorship of the Ministerio de Educación and the Colombian Academy of History, of which he was a corresponding member. The Universidad Nacional Autónoma of Mexico also sponsored several lectures in that same year.

Restored to his chair in the University of Valencia in 1961, Ots offered courses in his specialty on the doctoral level until his retirement in 1971. The last years were spent in Benimodo and in Valencia. Despite the partial loss of vision, he continued his investigations and carried on an active correspondence with his colleagues and friends on this side of the Atlantic.

The deceased was a prolific author both of books and of shorter studies in reviews, and even in some daily newspapers. Among others, his articles have appeared in:

Revista de las Indias (Colombia); Anuario de Historia del Derecho Español (Spain), of which he was founder together with Claudio Sánchez Albornoz (1924); Tierra Firme (Spain); The Americas, The Hispanic American Historical Review (United States); Humanidades (Argentina); Trimestre Económico, Revista de Historia de América (México); and in the newspapers El Tiempo (Bogotá) and La Prensa (Argentina).

Among his numerous books, these are especially noteworthy:

El derecho de familia y el Derecho de sucesión en nuestra legislación de Indias, Madrid, 1920;

La condición jurídica de la mujer en la legislación de Indias, Madrid, 1922;

Los más grandes cultivadores de la Historia del Derecho, Valencia, 1924 (Separata de los "Anales de la Universidad de Valencia");

Las instituciones sociales de la América española durante el período colonial, La Plata, 1934;

Las instituciones económicas bispanoamericanas del periodo colonial, Madrid, 1934;

El regimen municipal en Hispano-América: Concejos y ciudades, Madrid, 1937 (Separata de "Tierra Firme");

Estudios de Historia del Derecho Indiano, Bogotá, 1940 (Several articles published in journals are reprinted here);

El Estado Español en Indias, México, 1940 (Later, the Fondo de Cultura Económica published three more editions, the last in 1958, each revised); 
El siglo XVIII español en América (El gobierno político del Nuevo Reino de Granada. Apuntes documentales), México, 1947;

El regimen de la tierra en la América española durante el periodo colonial, Santo Domingo, 1946. (This is the text of the short course given at the Universidad de Santo Domingo. Later it was rewritten and published by the Fondo de Cultura Económica as España en América. El regimen de tierras colonial, México, 1966);

Nuevos aspectos del siglo XVIII español en América. Bogotá, 1946;

Las instituciones de gobierno del Nuevo Reino de Granada en el siglo XVIII, Bogotá, 1947;

Las instituciones del Nuevo Reino de Granada en visperas de la Independencia, Madrid, 1954;

(These last three books which Ots called "Instituciones del Derecho Indiano del siglo XVIII en América" resulted from his research in the Archivo Nacional de Colombia under a grant from the Rockefeller Foundation).

España en América. Instituciones coloniales, Bogotá, 1952;

Instituciones, Barcelona, 1959 (This is volume XIV of "Historia de América y de los pueblos americanos" directed by Antonio Ballesteros y Beretta);

The Impact of the Wars of Independence on the Institutional Life of the New Kingdom of Granada, Washington, D.C., 1960 (Traduc. de R.F. Mathias Kiemen. Separata of vol. XVII of the review of the Academy of American Franciscan History, The Americas.);

Solórzano y la Política Indiana en colaboración con Javier Malagón, México, 1965;

Manual de Historia del Derecho Español en América y del Derecho propiamente Indiano, Madrid, 1966. (Originally published in two volumes by the Universidad de Buenos Aires, it was reprinted by a private printer in Buenos Aires, 1945. This Madrid edition is an enlarged version of the first edition.)

Ots wrote numerous introductions for the works of other scholars. Among these should be mentioned that to the new edition of Politica Indiana of Juan de Solórzano, printed in Madrid, 1930, in five volumes. 